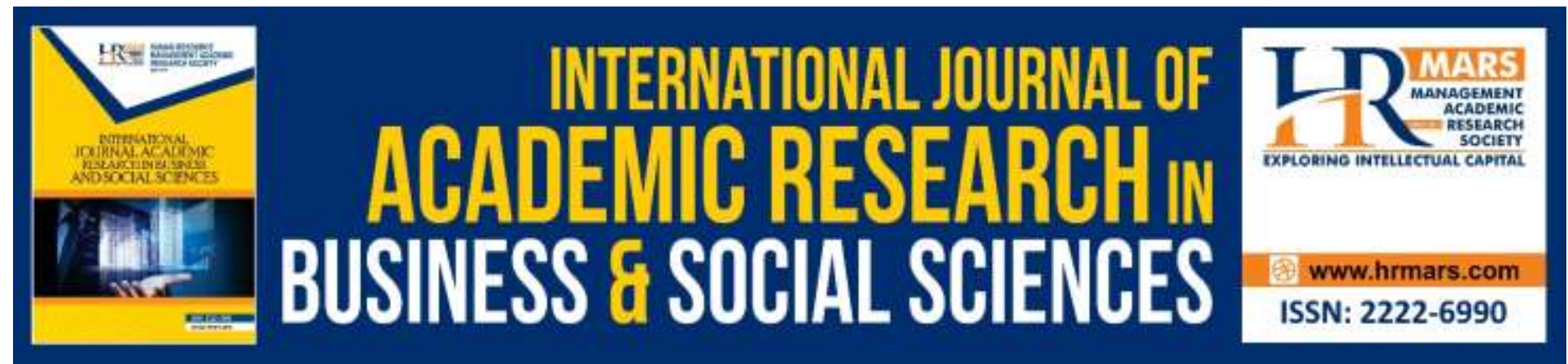

\title{
The Impact of Non-Financial Measurements in Market Trader's Business Performance
}

\section{Ainon Ramli, Rosmaizura Mohd Zain}

To Link this Article: http://dx.doi.org/10.6007/IJARBSS/v9-i9/6327

DOI: $10.6007 /$ IJARBSS/v9-i9/6327

Received: 08 July 2019, Revised: 12 August 2019, Accepted: 02 September 2019

Published Online: 23 September 2019

In-Text Citation:(Ramli \& Zain, 2019)

To Cite this Article: Ramli, A., \& Zain, R. M. (2019). The Impact of Non-Financial Measurements in Market Trader's Business Performance. International Journal of Academic Research in Business and Social Sciences, 9(9), 514-536.

Copyright: (C) 2019 The Author(s)

Published by Human Resource Management Academic Research Society (www.hrmars.com)

This article is published under the Creative Commons Attribution (CC BY 4.0) license. Anyone may reproduce, distribute, translate and create derivative works of this article (for both commercial and non-commercial purposes), subject to full attribution to the original publication and authors. The full terms of this license may be seen at: http://creativecommons.org/licences/by/4.0/legalcode

Vol. 9, No. 9, 2019, Pg. 514 - 536 


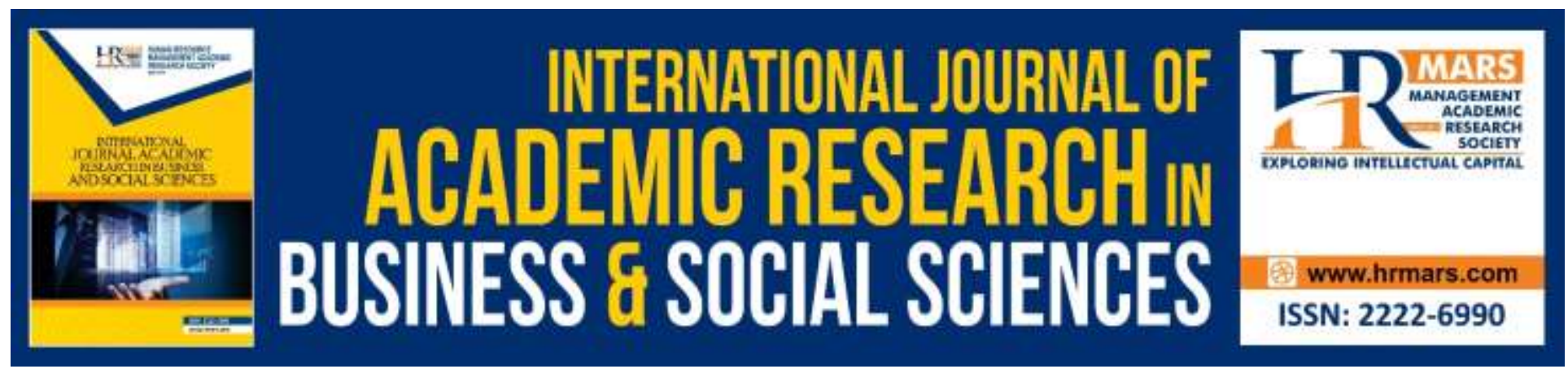

\title{
The Impact of Non-Financial Measurements in Market Trader's Business Performance
}

\author{
Ainon Ramli, Rosmaizura Mohd Zain \\ Faculty of Entrepreneurship and Business, Universiti Malaysia Kelantan. \\ Email:ainon@umk.edu.my
}

\begin{abstract}
Market trader is one of the sectors in Micro Enterprises (MEs) which is still unrecognised by the government because its contributions to the economic growth are unclear. This study aims to identify the depth of cash flow management, inventory management and accounting information usage in decision-making by market traders, and also looks at access to capital as a means to support to improve business performance and business expansion. Using a quantitative approach, the questionnaire was distributed to 300 market traders in PengkalanChepa, Kelantan, Malaysia. Using a Statistical Packages for Social Science (SPSS) version 25 to analyse the data, the study revealed that only cash flow management significantly influenced business performance of the market traders, while access to capital, inventory management and accounting information do not significantly impact their business performance. This study is important as a guidance to current market traders and those who are keen to venture into small businesses as market traders. The findings also provide information to agencies directly involved with market traders such as Amanahlkhtiar Malaysia (AIM), Majlis Amanah Rakyat (MARA) and TabungEkonomi Kumpulan UsahawanNiaga (TEKUN). Keywords: Market Traders, Business Performance, Cash Flow Management, Access to Capital, Inventory Management and Accounting Information.
\end{abstract}

\section{Introduction}

The Malaysian economic backbone consists of Micro, Small and Medium Enterprises (MSMEs). Their full-time employees and sales turnover are used to categorise the size of the companies as indicated in Table 1 (SME Corp 2018). A company with full-time workers less than five or having a sales turnover less than RM300,000 is considered a micro enterprise (MEs) in Malaysia. 
Table 1: Detailed definition by category of Micro, Small and Medium Enterprises in Malaysia

\begin{tabular}{|c|c|c|c|c|c|c|}
\hline \multirow[t]{2}{*}{ Size } & \multicolumn{2}{|l|}{ Micro } & \multicolumn{2}{|l|}{ Small } & \multicolumn{2}{|c|}{ Medium } \\
\hline & $\begin{array}{l}\text { Annual } \\
\text { Sales } \\
\text { Turnover }\end{array}$ & $\begin{array}{l}\text { Employe } \\
\text { es }\end{array}$ & $\begin{array}{l}\text { Annual } \\
\text { Sales } \\
\text { Turnover }\end{array}$ & $\begin{array}{l}\text { Employe } \\
\text { es }\end{array}$ & $\begin{array}{l}\text { Annual } \\
\text { Sales } \\
\text { Turnov } \\
\text { er }\end{array}$ & $\begin{array}{l}\text { Employe } \\
\text { es }\end{array}$ \\
\hline $\begin{array}{l}\text { Manufactur } \\
\text { ing }\end{array}$ & $<\mathrm{RM} 300,0$ & & $\begin{array}{l}\mathrm{RM} 300,0 \\
00 \text { to < } \\
15 \\
\text { million }\end{array}$ & $\begin{array}{l}5 \text { to }<75 \\
\text { employe } \\
\text { es }\end{array}$ & $\begin{array}{l}\text { RM15 } \\
\text { million } \\
\text { to } \leq 50 \\
\text { million }\end{array}$ & $\begin{array}{l}75 \text { to } \leq \\
200 \\
\text { employe } \\
\text { es }\end{array}$ \\
\hline $\begin{array}{l}\text { Services \& } \\
\text { other } \\
\text { sectors }\end{array}$ & 00 & $\begin{array}{l}\text { employe } \\
\text { es }\end{array}$ & $\begin{array}{l}\text { RM300,0 } \\
00 \text { to }<3 \\
\text { million }\end{array}$ & $\begin{array}{l}5 \text { to }<30 \\
\text { employe } \\
\text { es }\end{array}$ & $\begin{array}{l}\text { RM3 } \\
\text { million } \\
\text { to } \leq 20 \\
\text { million }\end{array}$ & $\begin{array}{l}30 \text { to } \leq \\
75 \\
\text { employe } \\
\text { es }\end{array}$ \\
\hline
\end{tabular}

Source: SME Corp (2018)

According to statistics by the SME Corp (2018), about 76.5 per cent of companies in Malaysia are MEs compared to small (21.2 per cent) and medium (2.27 per cent) sized enterprise (see Table 2). MEs are already perceived as a vital job and income sources in a large number of the developing countries (Mead and Liedholm 1998; Munoz et al. 2015).

Table 2: No. of SME Establishments by sector and size

\begin{tabular}{|l|l|l|l|l|}
\hline \multirow{2}{*}{ Sector } & \multicolumn{4}{l|}{ No. of SME Establishments } \\
\cline { 2 - 5 } & Micro & Small & Medium & $\begin{array}{l}\text { Total } \\
\text { SMEs }\end{array}$ \\
\hline Services & 649,186 & 148,078 & 11,862 & 809,126 \\
\hline Manufacturing & 22,083 & 23,096 & 2,519 & 47,698 \\
\hline Construction & 17,321 & 17,008 & 4,829 & 39,158 \\
\hline Agriculture & 4,863 & 4,143 & 1,212 & 10,218 \\
\hline Mining \& Quarrying & 217 & 458 & 190 & 865 \\
\hline Total & 693,670 & 192,783 & 20,612 & 907,065 \\
\hline
\end{tabular}

Source: SME Corp (2018)

In India, Golla (2018) observed that 45 percent of the manufacturing sector's output and almost 40 percent of the country's total exports are from MSMEs. Moreover, nearly 117 million job opportunities are also provided all over the country. Furthermore, MSMEs in India manufacture more than 6,000 products, from traditional to high-tech items. Obviously, MSME establishments have a very significant role to play in the economic growth of the country.

Ingram (2019) characterizes micro and small enterprises (MSE) as 1). lower revenue and profitability; 2 ). smaller teams of employees; 3 ). small market areas; 4). sole or partnership 
ownership and 5)found only in limited areas. In line with that, market traders have been identified as a part of MEs business. They are small traders who conduct business in the morning market, night market, off the roadside, residential areas and in areas of public attractions (for example, around supermarkets, bus stations, government buildings, beach, outside school and factories areas), either on public or private land. Market traders can be classified as a place where retail business like a market or moving stalls (Ibrahim and Leng, 2003). Furthermore, MEs do not participate in marketing activities to the same degree or to the same extent as bigger small and medium-sized enterprises (SMEs) (Herhes, 2016). Hawking activities of either semi-static or seasonal which sell a variety of goods ranging from food and non-food items are also considered as part of market traders (Salleh 2012). In addition, market traders require a low capital to start a business with lower risk than larger enterprises. Market traders' business produce basic products and they are largely used by the public (Jamak, et al. 2014). Business activities conducted in small scale include burger stall operators, food stall hawkers, grocers, night market hawkers, construction and small-scale service operations (Jamak, et al. 2011).

Market traders help create more job opportunities for people in a country. It reduces most issues related to unemployment, decreases poverty rate and provides income to them and the country (Isa et al., 2008). They hold an important role in generating social and economic development of a country or place (Osotimehin et al., 2012). Jamak et al. (2014) pointed out that for most people with low income, market traders are able to reduce poverty rates through good productivity that is market-driven. At the same time, those involved as market traders help improve the country's economic development.

However, a study by Holden (2016) shows that during the first year of operation, there is 80-90 per cent failure rate for Malaysian SMEs. Earlier, Salazar et al. (2012) concluded that among the main reasons for business failure are lack of capital, lack of financial planning, excessive investment in fixed assets, low strategic and financial projection, unplanned growth and capital mismanagement. Often, lack of management skills lead these small companies into failure of managing their finance effectively, thus cause them some problems that are beyond their core business (Cassells and Lewis 2011; Isa et al. 2008; Williams and O'Donovan 2015). The possibility of success and failure is at the same rate during the beginning of business for MEs (Wanjohi, 2009) but because of their small scale enterprises, a simple management fault can cause the collapse of the businesses. Padachi (2010) claimed that employees, management techniques and accounting system are considered the internal factors that lead to the business success or failure.

Additionally, the lack of human resource competency affects the MEs. Most of their human resources have low level of education, and, thus fewer skills (Thaker et al. 2015). There are few studies that have examined the components of MEs individually. A study by Hairuddin et al. (2012) examines batik (textile) MEs through face-to-face interviews and focuses on the challenges and barriers of IT adoption among batik micro-enterprise in Malaysia. From the analysis, their study revealed that awareness, attitude, lacking knowledge, skills and funds play a major role in IT adoption among them. Jamak et al. (2011) studied the differences between the failed micro-enterprise owners and surviving micro-enterprise owners. Their study found that strong motivations and better marketing approaches are 
essential for the successful micro-enterprise owners compared to the failed microenterprise owners, who are lacking those qualities. In addition, management incompetency, poor sales and marketing skills as well as lacking competitiveness to keep up with rivals are the major causes for the failure of business venture among the micro-enterprise owners.

According to Salleh et al. (2012), night market trader is one of the activities that contributes to the MSMEs that have economic value. Kuo et al. (2012) is also keen to examine the culture and tourism experience as well as behavior patterns of the Taiwanese night markets. There is a lack of studies done to look on the business performance of market traders. Hence, in the context of Malaysia, more market traders' studies which focus on variable affecting the performance of their businesses are required. This study attempts to look at several selected factors such as cash flow management, access to financing, inventory management and accounting information by market traders in PengkalanChepa area of Kelantan, Malaysia, who are actively involved in entrepreneurship and business engagement. To ensure success or growth of market traders, proper business management practices are needed to be implemented. In addition, this study is significant to the government of Malaysia especially to relevant agencies that deal directly with the MEs such as TabungEkonomi Kumpulan UsahawanNiaga (TEKUN), Amanahlkhtiar Malaysia (AIM), SME Corporation Malaysia, and Majlis Amanah Rakyat (MARA); the business owners and also to the body of knowledge and future researchers.

\section{Literature Review}

Performance measurement system is a set of methods created by organizations to assess company performance (Ahmad and Zabri, 2016). Performance measurement in the current competitive setting is a significant management control instrument for businesses (Eltinay and Masri, 2014). Performance is a popular topic in business and management because performance measurements are important to show current performance as well as guide and lead business directions to the future. Business performance is an essential element in experimental research when it involves multidimensional business policies and complex concepts. Performance evaluations and measurements can bring potential opportunity and can also be utilised to analyse and see the level of achievement of a person, group or institution's activities according to certain characteristics (Örnek and Ayas, 2015). Business performance is the classification of task completion or achievement of business goal or objectives in accordance with the results or conclusions obtained the end of the business period (Yıldız et al. 2014). Business performance is one of the goals to maximise profit and wealth of the owners (Waweru and Ngugi 2014). It is a guide to the organisation's ability to use existing resources in a way that is efficient and effective by obtaining optimum results.

The prior literature grouped performance measures in terms of financial and non-financial or qualitative and quantitative benchmark (Ahmad and Zabri, 2016). Among the most popular financial dimension are productivity, growth, cash flow, return on investment, turnover, fixed assets, return on equity, return on assets and profits (Carton and Hofer 2010; Eltiney and Masri, 2014), while non-financial performance is related to market share, stakeholder satisfaction, customer satisfaction, communities, number of complaints, expertise of employees and number of employees (Mjongwana and Kamala, 2018; Eltiney and Masri, 2014). According to Yuliansyah and Razimi (2015), non-financial performances 
may not only improve organizational performance, but may also improve managerial performance. Financial performance measures usually are associated with profitability and costs (Kludacz, 2012).

To examine the different aspects of business performance for global and local organizations, a number of empirical studies have been done periodically. For example, Zuriekat et al. (2011) scrutinised the applications of numerous financial and non-financial performance measures indicated in the performance measurement systems literature. Their study shows that by incorporating various rigorous financial and non-financial measures in performance measurement systems, it brings benefits to the respective companies. Furthermore, Ahmad and Zabri (2016) examined the use of non-financial performance measurement system among manufacturing companies and explore the link between business environment, size of the firm, modern manufacturing technology, owner/manager involvement and the use of non-financial performance measures. Their results revealed that there are significant relationships between size of the firm, modern technology, involvement of owner/manager and the use of non-financial performance measures. Their study offers fresh empirical evidence on the use of non-financial performance measures and adds to a stronger comprehension of the contingency strategy in a production setting.

Meanwhile, Mjongwana and Kamala (2018) discovered the extent to which SMEs use nonfinancial performance measurement (NFPMs) in the hotel industry. In regards to the kinds of NFPMs used by SMEs, their findings indicated that customer-related measures were the three most commonly used NFPMs, namely: guest satisfaction survey, sales development and bed occupancy rate, and that the two less frequently used NFPMs were learning and innovation-related. Karel et al. (2013) mentioned that, enterprise performance criteria include turnover, costs, profit, economic value added, investments and period of arranged contracts. Furthermore, Blackburn et al. (2013) in their study, contributed to the understanding of the variables that affect the performance and development of SMEs. Their findings indicate that business size and age dominate performance and are more crucial than the owner's strategy and entrepreneurial traits. It was also discovered that having a business plan was definitely essential.

However, the impact of cash flow management, access to financing, inventory management and accounting information for business decision making on the performance of market traders is not get enough attention from the researchers, especially in Malaysia. Information on market traders is difficult to obtain, making this study necessary in order to assist entrepreneurs in this sector. Both financial measures (profits, value of fixed assets and revenue) and non-financial measures (business diversification and number of employees) are included in this study. All of these measures are vital to evaluate market traders' growth.

\section{Business Success Factors}

Business achievement and success in the market, albeit it may have different outcomes is referred to as business performance. This study takes into consideration four business success factors that may impact the performance of market traders. These four factors are 
cash flow management, access to capital, inventory management and accounting information for decision-making.

\section{Cash Flow Management}

It is crucial for a business to manage its cash flow and ensure it has sufficient cash to meet its needs and obligations. Belobo and Palser (2014) noted that the capacity of a company to conduct its business activities smoothly is determined by its operational cash. A business with poor cash may not survive and remain in business for a long time, as pointed out in the numerous sources in the background. Luo (2007) believed that business financial power can be secured by sound internal cash generation.

Cash flow from operations is the best way of achieving a stable business and providing the capability to manage business activities successfully. Abioro (2013) claimed that cash is the backbone of every business, big or small. Powerful cash management builds the adaptability and upper hand of a business in managing crisis or exploiting open doors as they emerge, at a short notice (Gyebi and Quain, 2013). A large portion of these substances do not plan money spending or conjectures, do not lead bank compromises and do not screen their money streams consistently (Bruwer, 2010). Regrettably, some of them need financial balances and give off an impression of being indifferent about their liquidity (Small Business Connect 2015). Numerous SMEs likewise adopt an inactive strategy to their money administration; depend on manual procedures or basic bookkeeping programming to deal with their finance even as their organizations develop (Enow and Kamala, 2016). In the long term, these organizations confront liquidity issues that will lead to their closure.

In another study, Uwonda and Okello (2015) explored how cash flow management determines SMEs' survival in Northern Uganda. Their research revealed unsubstantial use of cash flow management, particularly in cash flow forecasting; tax planning; budgetary control and financial statements interpretation. As a result, they concluded that most SMEs had downturn rates of long-term solvency and development. Myeni (2018) explored in depth strategies used by effective SME leaders in occupational health to handle cash flow to attain sustainability for more than 5 years. Finally, seven themes were discovered: External Professional Team, Budgeting, Systems and Processes, Payment and Contracting Terms, Management of Surplus Funds and Reserves, Understanding of Customer Procurement and Cash Flow Management Strategy Model.

Besides that, Ahmad (2016), explores the magnitude of cash management practices in MSE in four major states in the Peninsular Malaysia. The researcher's overall results have shown that cash management practices are significant in these states. However, internal cash management control has a very low level of implementation. Thus, capital providers need to re-educate entrepreneurs on the significance of strong internal control over cash management to prevent manipulation, money shortages and other financial problems. Meanwhile, Smirat (2016) empirically examined cash management methods and their impact on SMEs' financial performance in Jordan. The research found that only 32 percent of SMEs kept track of money receipts and payments, and most ( 6 percent) of respondents had no expertise of cash control mechanisms. His study concluded that the practices of cash management impact SMEs' financial performance. Therefore, it cannot be denied that cash 
is a significant current asset for company operations. This research is therefore capable of filling the gaps as there are limited studies on cash flow management in Malaysia, especially MEs.

\section{Access to Financing}

Access to financing is one of the most important aspects in the development of SMEs. According to Lee et al. (2018), the aftermath of the 2008 financial crisis triggered focus on access to financial capital for SMEs. In a study, Wulandari et al. (2017) measures farmers' knowledge of the requirements to obtain financing with the actual requirements set by various different types of financial providers, and probes the relation between demographic and socioeconomic factors to farmers' knowledge of financing requirements. The researchers found that the most important requirements to secure loans vary among different financial provider types. They also observed that farmers generally have little knowledge of the requirements vital to each type of financial provider. For that reason, to increase farmers' knowledge of the diverse requirements among the financial provider types, awareness campaigns are needed.

Nonetheless, access to capital is a common obstacle to a new business, especially small businesses which are known to have limited payback capabilities compared to large-scale businesses. Although most countries are developing countries, providing micro-credit loans to them and access to capital remains volatile, and it is one of the biggest problems for small businesses. Lacking access to capital and credit assistance, as well as financial system hurdles are viewed by potential entrepreneurs in the developing economy as the primary challenges to their business innovation and achievement. Wulandari et al. (2017) summarised that the previous researches have highlighted various types of financial providers, and lack of access to funding is a significant problem for rural poor people, particularly in developing countries.

Furthermore, Manaye and Tigro (2017) identified the challenges that small businesses in WolaitaSoddo town face in accessing finance from financial institutions by identifying the dominant means of financing small businesses and factors influence the extent of securing financing. From the findings, it can be inferred that sources of initial capital influences accessibility to credit facilities to a great extent followed by purchase of fixed assets financed by credit facilities. Their study also concludes that the respondents were inclined to get their start-up capital from personal savings, relatives and friends because financial institutions require collateral and high repayment costs.

Practically, the primary source of financing for medium-sized businesses are financial institutions. However, most micro and small businesses rely on their own internal resources for funding. In Malaysia, Hassan et al. (2010) analysed financial opportunities and constraints faced by the micro-enterprise entrepreneurs. Generally, during the initial startup phase, micro-enterprise entrepreneurs face financial obstacles the most. Yet, a significant number of them have not tapped into the funds provided by the banks. In fact, for business loans and financing needs, only $10 \%$ of MEs reported that they relied on the financial establishments (Bank Negara Malaysia 2005). 
According to Chowdhury (2013), majority of the market traders are found to have secured funds for their initial setup and procurement of raw materials needs. However, market traders who need to finance their business have problems to get it from conventional financing. Hence, most of them prefer to use savings and personal contributions from their immediate family such as siblings, as they feel it is difficult to get loans from bank due to the rigid requirements such as collateral and substantially high costs of repayment (Kamunge al. 2014; Kithae et al. 2012). Those studies also found that access to finance affected their business performance.

Another related study (Gichuki et al. 2014) also approved market traders' choice of obtaining their start-up capital from individual funds, relatives and friends in light of the security requirements and high payment costs by financial institutions. Market traders are likewise viewed as high hazard borrowers as a result of their low capitalisation, lacking resources and high death rates, thus banks are not quick to offer them credit at similar loan fees. Market traders in the fare segment additionally confront issues of access to working capital.

Other actual problems that have led to market traders' poor results include: restricted access to long-term capital and high cost of short-term funding, with organisational capacity being the biggest or worst issue facing market traders. However, business success does not rely solely on the availability of access to capital or financing from formal financial institutions (Ogbo and Hukwu, 2012). Piperopulos (2010) signified that in various studies, specialists have discovered that ethnic minority organizations have never utilised or approached business for money related help from banks and other monetary establishments and subsequently they depend on individual reserve funds and ethnic pleasant assets. Padachi (2010) classified those fundamental factors that add to progress or disappointment of small business as inner and outer elements. The outside components include financing (for example, the accessibility of alluring financing).

Evidences in these studies show that most of the funding from the private sector and the government goes to the two components of SMEs, namely, the small and medium enterprises. While the third component, the MEs, hardly receive considerable funding from the private and public institutions (Hassan et al. 2010; Selamat et al. 2011). MEs are seen as risky business. Hence, most of them have to rely on the internal funding from family members, friends and their savings. Furthermore, due to lack of funding and proper attention, MEs suffer from human capital deficiency with low level of education and insufficient human capacity for development (Thaker et al. 2015). Given the positive impact of MEs and the limited studies on micro-enterprise business performance, the objective of this study is to examine the factors that affect and shape micro-enterprise performance (in the context of financial and non-financial measure) to the market traders in Malaysia.

\section{Inventory Management}

Inventory management is one of the most essential elements in business activities because it is related to sales. As supported by Nyang'au (2013), the success of MSMEs depends on effective inventory management. Without proper inventory management, the company may have a shortage of inventory to meet market demand. On the other hand, if excessive 
inventory is stored, it will negatively affect the company's cash flow and cause other problems such as inventory damage, theft, expiration date, storage space and so forth.

Besides that, the successful factor of an organization can be determined if the organization have an efficient and effective inventory management so the level of difficulties can be reduced in handling the operations. Therefore, in order to achieve effective inventory management, an organization must pay attention in order to control inventory expenses (Ferencikova, 2014). In addition, the business must set objectives to control the resources so it can be available whenever it has the demand as this can lead to better business performance.

However, to achieve the effective inventory management, there are also problems that will occur such as underproduction, overproduction, delay in raw materials delivery, inventory discrepancy and stock out situation (Chan et al. 2017). This is supported by Waters (2003), who stated that when the stocks are lower than the demand of the market, it is known as underproduction because there is no stock left in the warehouse which can be immediately transferred to customers. It is a disadvantageous situation because it can reduce the profits of the company and cause low performance if it recurs. It can also make the customer feel unhappy and dissatisfied, thus leading to loss of sales numbers in the market.

On the contrary, Muller (2011) noted that when the production is more than the demand of the customer, it is called as overproduction. When overproduction occurs, it can lead to waste of resources such as money, stocks, space of the storage and the efforts from the operation. This is because when stocks are over the demand, the excess stocks will not be sold and can get damaged, thus leading to loss.

Another problem faced by most organizations is stock out situation. Stock out situation is conditions when customers want to buy a product but ends up with no stocks. This situation will lead to dissatisfaction among customers due to the production issue and can affect the performance of business. As stated by Waters (2003), when there is a lack of stocks, the customer will not wait for the order that have been made and this will result in the decrease of sales in an organization.

Hence, to maintain the quantity of the stocks that is in line with the demand of customers is the most crucial part because the production itself have tried to avoid the waste of money and resources that are not used. This is because when excessive resources are not being utilised, it can really impact the cost of managing facilities (Kamau and Kagiri, 2015).

Furthermore, Esther (2012) mentioned that the results of the stock out situation will have negative effects on the employees, equipment and customers, and this will lead towards the decreasing sales and unsatisfied customers. Sometimes when we make an order to the supplier, it can be too long for the delivery of the raw materials (Waters 2003). Then, the delay of the raw materials will affect the production of the product. 
The other problems that arise related to the inventory management is discrepancy of inventory. Discrepancy of inventory means that the actual stocks in hand are not the same as the stocks in systems. Stocking is a common action that shows the recording amount of the inventory (Waters 2003). As supported by Kamau and Kagiri (2015), the result from the discrepancy of inventory is the profit loss for an organization.

In one study, Chan et al. (2017) identifies the issue of inventory management experienced by small and medium-sized companies and also recognises variables that will affect inventory management efficiency. The study indicated that overproduction, underproduction, stock out situation, raw materials delivery delay and records discrepancy are the inventory management challenges faced by manufacturing organizations. Other factors that have substantial impacts on the efficiency of inventory management are documentation/document storage, planning, employee/staff skills knowledge. Meanwhile, funds have only a slight important effect on the inventory management of small and medium-sized manufacturing businesses.

In short, effective inventory management is critical to the successful running of MSEs.Nyang'au (2013) focused on the concerns of inventory management for micro and small businesses (MSEs) in Kisii Town, Kenya. Some of the problems of inventory management include variability in demand, processing of materials, inventory expenses, insufficient data and stock setting. There is a lack of studies done about micro-enterprise (market traders) in Kelantan although past studies have shown that there are several variables affecting the efficiency of organizations' inventory management. Therefore, this study aims to determine the efficiency of micro-enterprise inventory management.

\section{Accounting Record Keeping and Use of Accounting Information for Decision Making}

In micro and small businesses like night market and wet market, financial management is also similarly important just like a big company or high-level business (Zager and Decman, 2016) in order to maintain their business performance. This is because financial management such as accounting records represents a great source of information for the business to make the right decision to sustain their performance (Sacer et al. 2016). In business strategic plan, tactical and operational decision should be based on quality information. Therefore, information from the accounting reliability is precondition for a sound decision-making process (Sacer et al. 2016). Since accounting records reflect a company's financial management and business efficiency, they are an inevitable source of decision-making (Sacer et al. 2016). On a similar note, bookkeeping without properly preparing records or reports is probably not fruitful in aiding decision making unless the reports are accurately prepared and analysed to help decision makers. Abanis et al. (2013) studied the practice of financial management analysis by small enterprise and discovered that their managerial decisions were mostly based on their accounting records as well financial reports.

Making accounting records are actually quite complex for market traders since they are micro entity business (Sacer et al. 2016), where the flows of their finance are in a small amount. They might think that they do not need to record all transactions due to the complexity of the process. Actually, accounting records can predict and estimate the future 
of the business. Accounting records such as journal, ledgers and sub ledgers are important information to predict whether the business can go further or not (Zager and Decman, 2016). This is because the owner of the business needs to make a prediction between the period of time when they borrow money and gain profit. Another financial information that can be observed is the additional expenses such as taxes and utilities that must be paid to conduct business at the market. This is because micro business is very different from large ones in terms of borrowing, lacking of debt finance and having different taxation provisions (Jindrichovska, 2013).

Other than that, accounting records among market traders is also a critical component of financial management. In spite of their economic importance, one of the problems that is generally faced by the market traders is the absence of access to funding which is aggravated by market traders' inability to extract and use quality accounting information (Erambo et al. 2016).

Besides poor accounting or non-existence of accounting information, management is also unassertive and may face a hard situation to make decisions. Nevertheless, this kind of situation is improving from time to time as they put forward the improvement of accounting systems by computerising them, resulting in the enhancement of financial reporting standard. Indeed, For MEs in Malaysia, this quantitative study/research is valuable because it offers guidelines to ME employers in PengkalanChepa, Kelantan.

Based on the discussions above, the model for this current study is developed as illustrated in Figure 1 below.

Figure 1: Conceptual Framework of the Study

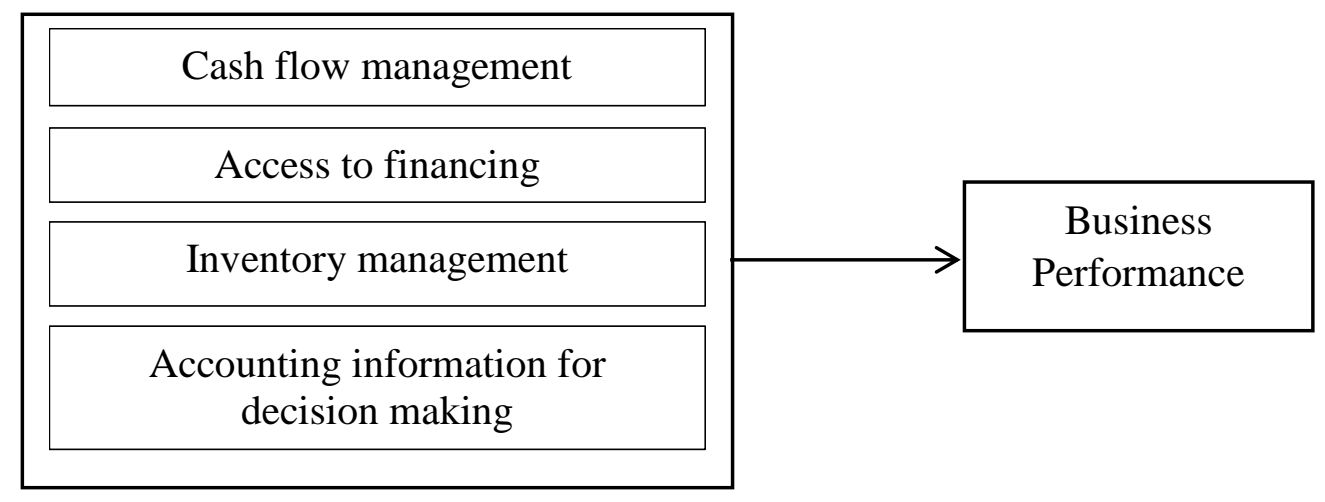

\section{Research Design}

This empirical study is to explore the relationships between four factors and business performance (Figure 1 above) of market traders in PengkalanChepa area of Kelantan. The study used a self-administered questionnaire distributed to the target respondents from four morning and night markets. The total population of market traders for this current study is unknown because their businesses are not registered. A total of 300 questionnaires were distributed randomly; however, only a total of 199 usable questionnaires were 
collected. A Statistical Packages for Social Science (SPSS) version 25 was used to run the distribution, correlation and regression analyses to test the hypotheses.

\section{Findings and Discussion}

\section{Descriptive Analysis}

Table 3: Profile of respondents

\begin{tabular}{|c|c|c|c|c|c|c|c|c|}
\hline Gender & $\mathrm{N}$ & $\%$ & Age & $\mathrm{N}$ & $\%$ & Races & $\mathrm{N}$ & $\%$ \\
\hline Male & 133 & 66.8 & Below 30 & 49 & 24.6 & Malay & 196 & 98.5 \\
\hline Female & 66 & 33.2 & 30-39 & 47 & 23.6 & Others & 3 & 1.5 \\
\hline \multirow[t]{3}{*}{ Total } & 199 & 100.0 & $40-49$ & 55 & 27.6 & Total & 199 & 100.0 \\
\hline & & & 50 and Above & 48 & 24.1 & & & \\
\hline & & & Total & 199 & 100.0 & & & \\
\hline $\begin{array}{l}\text { No. of years in } \\
\text { business }\end{array}$ & $\mathrm{N}$ & $\%$ & Job status & $\mathrm{N}$ & $\%$ & Education level & $\mathrm{N}$ & $\%$ \\
\hline Less than 1 & 11 & 5.5 & & 154 & 77.4 & Primary school & 10 & 5.0 \\
\hline$>1-<5$ & 63 & 31.7 & Part-time & 45 & 22.6 & $\begin{array}{l}\text { PMR/SRP(secondary } \\
\text { school level 1) }\end{array}$ & 25 & 12.6 \\
\hline$>5-<10$ & 19 & 9.5 & Total & 199 & 100 & $\begin{array}{l}\text { SPM/STAM(secondary } \\
\text { school level 2) }\end{array}$ & 132 & 66.3 \\
\hline$>10-<15$ & 80 & 40.2 & & & & Matriculation/ Diploma & 22 & 11.1 \\
\hline$>15-<20$ & 22 & 11.1 & & & & Degree & 7 & 3.5 \\
\hline More than 20 & 4 & 2.0 & & & & Not attending school & 3 & 1.5 \\
\hline Total & 199 & 100 & & & & Total & 199 & 100 \\
\hline $\begin{array}{l}\text { Job before start } \\
\text { the business }\end{array}$ & $\mathrm{N}$ & $\%$ & $\begin{array}{l}\text { No of years in } \\
\text { a pay job } \\
\text { before start } \\
\text { the business }\end{array}$ & $\mathrm{N}$ & $\%$ & & & \\
\hline $\begin{array}{l}\text { Market trader } \\
\text { is the first job }\end{array}$ & 94 & 47.2 & $\begin{array}{l}\text { Less than } 5 \\
>5-<10\end{array}$ & $\begin{array}{l}41 \\
29\end{array}$ & $\begin{array}{l}50.6 \\
35.8\end{array}$ & & & \\
\hline $\begin{array}{l}\text { A paying job } \\
\text { (working in } \\
\text { other }\end{array}$ & 81 & 40.7 & $>10-<15$ & 8 & 9.9 & & & \\
\hline companies) & 24 & 12.1 & $>15$ & 3 & 3.7 & & & \\
\hline $\begin{array}{l}\text { Full-time house } \\
\text { wife } \\
\text { Total }\end{array}$ & 199 & 100.0 & Total & 81 & 100.0 & & & \\
\hline
\end{tabular}


Majority of the respondents are males (66.8\%) with females are only about $33 \%$. There is roughly an equal involvement in the business with regard to their ages. There are about $49 \%$ of entrepreneurs at the age of 39 and below, and about $51 \%$ at the age of 40 and above. PengkalanChepa is a place of Malay residential area and thus Malays constitute the biggest involvement in the business as market traders $(98.5 \%)$ with the rest of three respondents (1.5\%) comes from other races. Majority $(66.3 \%)$ of the respondents completed their secondary school level two at the age of $17 ; 10$ respondents or $5 \%$ only attended school until the age of 12 for their primary school; only about 15\% from total respondents have obtained a higher education at diploma or degree levels. There are three respondents of other races who do not attend school because they are immigrants from other countries (Cambodia and Siamese of Thailand).

Out of total respondents, approximately $77 \%$ of them running the business as their full-time job and the rest (about 23\%) only become market traders on part-time basis. More than $53 \%$ of them have engaged more than 10 years in their respective businesses, which are considered matured businesses. This is followed by $9.5 \%$ in the business between 5 to 10 years, and only $5.5 \%$ respondents newly started the business in less than a year.

Of the total respondents, about $47 \%$ are starting the business as their first job, which means they do not have experience working with other people. $12 \%$ were housewives and about $41 \%$ were in other paying job before starting their businesses. Another question was asked for those who are working in other paying jobs with majority of them (about 51\%) worked for less than 5 years before deciding to quit the job and starting their own business. About $36 \%$ and $10 \%$ worked between 5 to 10 years and 10 to 15 years respectively.

\section{Reliability Test}

The reliability test is a mechanism to check the internal consistency of a scale by using the alpha coefficient of Cronbach as an indication of the degree of consistency. Ideally, the Cronbach's alpha value should be above 0.7 (Nunnally 1967). However, Hinton et al. (2004) claimed that an alpha score between 0.5 to 0.70 is generally accepted as indicating a moderately reliable scale. The lowest Cronbach's score in this study is 0.638 (Table 4) for cash flow management and thus, all items in this study are retained for further tests.

Table 4: Summary of the Cronbach's Alpha

\begin{tabular}{|l|l|l|}
\hline Variable & $\begin{array}{l}\text { Cronbach's } \\
\text { Alpha }\end{array}$ & $\begin{array}{l}\text { No. of } \\
\text { items }\end{array}$ \\
\hline Business Performance (BP) & 0.738 & 5 \\
\hline Cash Flow Management (CFM) & 0.638 & 5 \\
\hline Capital Structure (CS) & 0.710 & 5 \\
\hline Inventory Management (IM) & 0.653 & 5 \\
\hline Accounting Information (AI) & 0.934 & 5 \\
\hline
\end{tabular}

\section{Correlation Analysis}

The Product Moment Correlation coefficient of Bivariate Pearson is used to assess the correlation between the variables. The $r$ value can interpret the strength of the relationship 
(Cohen 1988). Table 5 shows the summary of the results with all independent variables have at least 30\% significant relationship with the dependent variable (Pallant 2013) except for accounting information which has the value of -0.114 which is also not significant to influence performance. Thus, the accounting information is deleted from further test. According to Tabachnick and Fidell (2007), the relationship between independent variables should not exceed 0.70 and if the $r$ value is more than the 0.70 , omitting one of the variables is recommended. Referring to Table 5 the correlation $r$ value for all the independent variables are less than 0.7, this indicates that none of the independent variables are highly correlated and that all the variables are retained (except for accounting information).

Table 5: Bivariate Pearson's Product Moment Correlation

\begin{tabular}{|c|c|c|c|c|c|}
\hline & CFM & CS & IM & $\mathrm{Al}$ & BP \\
\hline CFM & 1 & & & & \\
\hline CS & $.364^{* *}$ & 1 & & & \\
\hline IM & $.623^{* *}$ & $.383^{* *}$ & 1 & & \\
\hline AIM & .015 & $-.379^{* *}$ & -.035 & 1 & \\
\hline BP & $.641^{* *}$ & $.305^{* *}$ & $.470^{* *}$ & -.114 & 1 \\
\hline
\end{tabular}

\section{Multiple Regression}

Multiple regression is used to examine the impact of the factors in this current study on business performance. The R Square of this model is 0.433 (Table 6), which indicates that this model explains $43.3 \%$ of the variance in the business performance.

Table 6: Coefficient Value of the Model

\begin{tabular}{|l|l|l|l|l|}
\hline Model & R & R Square & Adjusted R Square & $\begin{array}{l}\text { Std. Error of the } \\
\text { Estimate }\end{array}$ \\
\hline 1 & $.658^{\mathrm{a}}$ & .433 & .421 & 3.31285 \\
\hline
\end{tabular}

a. Predictors: (Constant), AI, CFM, CS, IM

b. Dependent Variable: BP 
INTERNATIONAL JOURNAL OF ACADEMIC RESEARCH IN BUSINESS AND SOCIAL SCIENCES

Vol. 9, No. 9, September, 2019, E-ISSN: 2222 -6990 @ 2019 HRMARS

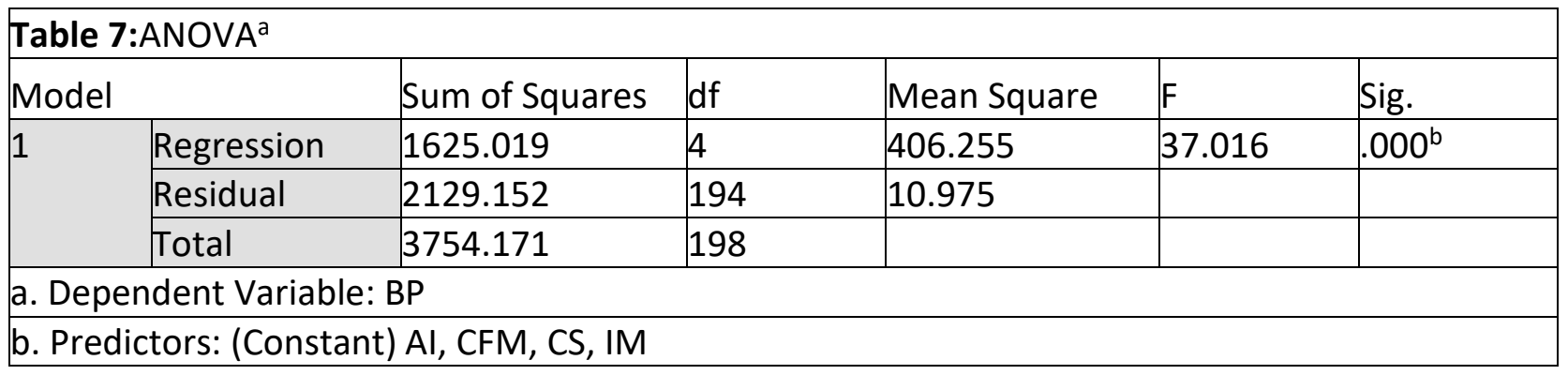

Referring to Table 8, the largest standardised coefficient beta is 0.572 , which is contributed by cash flow management (CFM). This indicates that CFM has the strongest unique contribution in explaining the dependent variable. This is the only variable that makes the significant contribution to the prediction of the dependent variable in this study.

Table 8: Coefficient of Dependent Variable

\begin{tabular}{|c|c|c|c|c|c|c|}
\hline \multirow[b]{2}{*}{ Model } & & \multicolumn{2}{|c|}{ Unstandardised Coefficients } & \multirow{2}{*}{$\begin{array}{l}\text { Standardised } \\
\text { Coefficients } \\
\text { Beta } \\
\end{array}$} & \multirow[b]{2}{*}{$\mathrm{t}$} & \multirow[b]{2}{*}{ Sig. } \\
\hline & & $\mathrm{B}$ & Std. Error & & & \\
\hline \multirow[t]{5}{*}{1} & (Constant) & 3.241 & 2.436 & & 1.331 & .185 \\
\hline & CFM & .654 & .081 & .572 & 8.087 & .000 \\
\hline & CS & .021 & .102 & .013 & .206 & .837 \\
\hline & IM & 157 & .106 & .105 & 1.484 & .139 \\
\hline & Al & -.071 & .037 & -.113 & -1.906 & .058 \\
\hline
\end{tabular}

a. Dependent Variable: BP

\section{Discussions}

This study focused on the four factors that affect the market traders' business performance. The first factor of accounting information for decision making has a high Cronbach's alpha (0.90), but the value of correlation with business performance is negative $(-0.10)$, which is less than 0.30, and thus, is not reliable as suggested by Pallant (2013) and also insignificant. Therefore, this factor is removed from further test. Fundamentally, accounting is essential and it is considered as a language of business. The use of a proper accounting system by the market traders in PengkalanChepa is unfortunately unsatisfactory. There are no systematic records regarding their business transactions with some of them only jot down in the book, the amount of income and expenses. Consequently, their notes do not help them much in making important business decisions. They argued that systematic records are too difficult to do with the fact that they do not have knowledge in bookkeeping. The data of the respondents' profile shows that the highest qualifications of the respondents (about 66\%) were only at secondary school level two (SPM) at the age of 17. The respondents might not have enough knowledge and skill to manage accounting records properly and it is actually quite complex for micro entity business to practise (Sacer et al. 2016). This result perhaps due to the nature of the business activities of the market traders which is very different from the large ones in the area of borrowing, lacking of debt finance and different taxation provisions (Jindrichovska, 2013). The absence of accounting records and financial statements left market traders without clue on business performance. They are also not 
able to make the best business decisions for better success, survival and expansion of the business.

Market traders usually run a cash-based business where all business transactions are in cash. Therefore, cash flow management is important in their business as evidenced in the results. The correlation between cash flow management and performance is significant and valued at 0.64 , which is the highest among all factors in this study. Regressions results indicate that this factor is very essential and the only significant influencing factor to impact their business performance with beta value of 0.50 . This factor alone contributes to R2 value of 0.422 in which more than $42 \%$ of this factor affects business performance of market traders. This finding is supported by Ahmad (2016), where cash management practices are very prevalent among micro and small businesses, most of which have implemented solid practices in their cash management. This current study is further proof that market traders have the ability to manage their cash well. The results also confirmed the finding that most of small businesses have efficient internal control of cash flow (Sunday et al. 2013). To conclude, cash flow management is vital to all kind of businesses especially small-sized enterprises to ensure the best business performance.

Furthermore, this study recorded insignificant result of capital structure to influence the business performance, which is similar to the finding of Kinyua (2014) where lack of access to capital base is almost universally identified as the core problem for small businesses. Meanwhile, Piperopulos (2010) agreed that market traders using their own money to run the business. Barriers to credit forces the market traders to rely on self-financing or borrowing from families and friends which limits them from running the business optimally. Respondents in this current study stated that they need financial aid from the government or financial institutions to expand the business but failed to secure them because of the inability to meet tedious documentation requirements, inconvenient repayment methods and high interest rates. This is in agreement with the statement from Petersen and Rajan (1994) and Berger and Udell (1995), where market traders just depended solely on financing sources from individual investment funds or borrowings from families and friends. They are also more interested in obtaining help from family and friends because it is easier than getting formal help due to certain conditions that are more stringent that need to be complied with.

Finally, the last factor of inventory management is also unimportant to influence business performance. The market traders revealed that they bought stocks for current use only. They do not maintain many stocks because it requires a lot of cash. Majority of them do not have enough capital to buy stocks in large quantities and take bulk purchase discount. Almost all of them also do not have a complete record for the stocks purchased. Therefore, they do not know the actual cost of the goods sold. There is inefficient decision-making and insufficient knowledge to manage inventory systematically that impact their business performance. This finding is consistent with the previous study (Alrjoub and Ahmad, 2017) where they found that total inventory kept by small businesses is not significant with enterprise performance. Similarly, a study by Bawa et al. (2018) came to the same conclusion when the results showed an insignificant negative impact of inventory management with the firm performance of manufacturing firms in Ghana. It is also in 
agreement with a study by Folinas and Shen (2014), who found no significant correlation between inventory turnover and financial performance. An increase in inventory turnover and sales performance depends upon the firm's size (Gaur and Kesavan, 2009). The record of inventory movement is important for inventory planning and optimisation as business performance requires an effective inventory management practice of inventory planning (Waters, 2003). Therefore, knowledgeable owner is crucial in assuring effective inventory management.

\section{Conclusions and Recommendations}

This study has provided insight into the practices of market traders about the accounting record keeping to provide business information to guide decision-making, cash flows management, access to financing and inventory management. It recommends relevant agencies to enhance their role in helping market traders such as facilitating access to capital by providing micro loans that do not burden borrowers, providing ongoing free training to increase business motivation as well as to teach and guide them on how to record business transactions, using information from the records to make business decisions, inventory management and efficient cash management. They need to be exposed to the effective business management to improve their business profitability and efficiency. With the background of the respondents, a majority of whom have education up to secondary school level two, they do not have enough business knowledge to stay competitive in the market and to expand the business. This is one of the reasons for some of them to remain microsized businesses for a long period (refer Table 1). Lack of awareness on financial support needs to be addressed, as some of them are unaware of its availability. This hinders them to get financial support to grow the business. Appropriate plans of access to financing should also be implemented to help them get financial support. Minimum interest rates with nonburdensome repayments are necessary. Hence, this study is useful to the market traders, especially in Kelantan to realize the importance of accounting record keeping and use of accounting information in business decision makings. They need to be aware about the availability of micro credit to help finance their business operations and to expand the business. Inventory management is important for market traders as excess stock will cause cash flow to be disrupted, while inadequate stock will negatively impact the business. Thus, market traders need business knowledge that is useful to them in business.

Lastly, future studies need to be undertaken to identify the challenges faced by market traders to enhance their business performance so that relevant government agencies can develop and implement policies that facilitate the survival of Malaysian market traders. This will be useful to the related government agencies to give more attention to the market traders as one of the important industry players and contributors to the Malaysian economy.

\section{References}

Abanis, T., Sunday, A., Burani, A., \& Eliabu, B. (2013). Financial Management Practices In Small and Medium Enterprises in Selected Districts In Western Uganda. Research Journal of Finance and Accounting, 4(2), 29-42.

Abioro, M. (2013). The impact of cash management on the performance of manufacturing companies in Nigeria. Uncertain Supply Chain Management, 1(3), 177-192. 
Ahmad, K., \& Zabri, M. S. (2016). The Application of Non-Financial Performance Measurement in Malaysian Manufacturing Firms. Procedia Economics and Finance, $35,476-484$.

Ahmad, N. N. (2016). Cash Management Practices in Micro and Small Businesses in Malaysia. Journal of Education and Social Sciences, 4, 331-335.

Alrjoub, A. M. S., \& Ahmad, M. A. (2017). Inventory management, cost of capital and firm performance: Evidence from manufacturing firms in Jordan. Investment Management and Financial Innovations, 14(3), 4-14.

Bank Negara Malaysia. (2005). SMEs Access to Financing. Retrieved from http://www.bnm.gov.my/files/publication/sme/en/2005/chap_6.pdf

Bawa, S., Asamoah, G. E., \& Kissi, E. (2018). Impact of inventory management on firm performance. A Case Study of Listed Manufacturing Firms in Ghana. International Journal of Finance and Accounting, 7(4), 83-96.

Belobo, A. B., \& Pelser, F. (2014). Cash Flow Management: Assessing Its Impact on the Operational Performance of Small and Medium Size Enterprises at the Mafikeng Local Municipality in South Africa Prior to the Global Financial Crisis. Mediterranean Journal of Social Sciences, 5(27), 226-234.

Berger, A. N., \& Udell, G. F. (1995). Relationship Lending and lines of credit in small firm finance. Journal of Business, 68, 351-381.

Blackburn, R., Hart, M., \& Wainwright, T. (2013). Small business performance: business, strategy and owner manager characteristics. Journal of Small Business and Enterprise Development, 20(1), 8-27.

Bruwer, J. P. (2010). Sustainability of South African FMCG SMME retail businesses in the Cape Peninsula. Published Master of Technology Thesis. Cape Town. Cape Peninsula University of Technology. Retrieved from http://etd.cput.ac.za/bitstream/handle/20.500.11838/1724/Bruwer_JP_MTech_Sus tainability\%20of\%20South\%20African.pdf?sequence=1\&isAllowed=y

Carton, R. B., \& Hofer, C. W. (2010). Organizational Financial Performance: Identifying and Testing Multiple Dimensions. Academy of Entrepreneurship Journal, 16(2), 1-22.

Cassells, S., \& Lewis, K. (2011). SMEs and environmental responsibility: Do actions reflect attitudes? Corporate Social Responsibility and Environmental Management, 18(3), 186-199.

Chan, S. W., Tasmin, R., A. H. Aziati, N. Rasi, R. Z., Ismail, F., \& Yaw, L. P. (2017). Factors Influencing the Effectiveness of Inventory Management in Manufacturing SMEs. IOP Conference Series: Materials Science and Engineering (pp. 1-8). Beijing, China.

Chowdhury, T. U., Datta, R., \& Mohajan, H. K. (2013). Green finance is essential for economic development and sustainability. International Journal of Research in Commerce, Economics and Management, 3(10), 104-108.

Cohen, J. (1988). Statistical power analysis for the behavioral sciences (2nd ed.). Hillsdale, NJ: Lawrence Erlbaum Associates.

Eltinay, N., \& Masri, R. (2014). Understanding Impact of Financial and Non Financial Measurements in Sudanese Banks' Performance. International Journal of Humanities and Management Sciences, 2(3), 98-104.

Enow, S. T. \& Kamala, P. (2016). Cash management practices of small, medium and micro enterprises in the Cape Metropolis, South Africa. Investment Management and Financial Innovations, 13(1), 230-236. 
Erambo, G. E., Mulwa, J. M., Aketch, J. R., Sangoro, O., \& Muchibi, W. M. (2016). Financial management practices and firm performance among micro and small enterprises in Busia Town, Kenya. International Journal of Management and Commerce Innovations, 4(2), 303-310.

Esmaeel, R. I., Zakuan, N., Jamal, N., \& Taherdoost, H. (2018). Understanding of business performance from the perspective of manufacturing strategies: fit manufacturing and overall equipment effectiveness. Procedia Manufacturing, 22, 998-1006.

Ferenčíková, D. (2014). Inventory Management in Small and Medium-Sized Manufacturing Companies and Its Main Dilemmas. Proceedings of the 2014 International Conference on Industrial Engineering and Operations Management (pp. 756-762). Bali, Indonesia.

Folinas, D., \& Shen, C. Y. (2014). Exploring Links Among Inventory and Financial Performance in the Agricultural Machinery. International Journal of Food and Agricultural Economics, 2(4), 1-12.

Gaur, V., \& Kesavan, S. (2015). The Effects of Firm Size and Sales Growth Rate on Inventory Turnover Performance in the U.S. Retail Sector. In Agrawal N., Smith S. (Eds.) Retail Supply Chain Management. International Series in Operations Research \& Management Science, 223). Boston, MA: Springer.

Gichuki, J. A. W., Njeru, D. A., \& Tirimba, O. I. (2014). Challenges Facing Micro and Small Enterprises in Accessing Credit Facilities in Kangemi Harambee Market in Nairobi City County, Kenya. International Journal of Scientific and Research Publications, 4(12), 1-25.

Golla, S. K. (2018). Growth and Performance of Micro Small and Medium Enterprises in India after MSMED Act 2006. International Journal of Research in Management, Economics and Commerce, 8(1), 52-59.

Gyebi, F., \&Quain, S. (2013). Internal Control on cash collection.A case of the electricity company of Ghana Itd, Accra East region. International Journal of Business and Social Science, 4(9), 217-233

Hairuddin, H., Md. Noor, N. L., \& Malik, A. M. (2012). Why do Microenterprise Refuse to Use Information Technology: A Case of Batik Microenterprises in Malaysia.Procedia Social and Behavioral Sciences, 57, 494-502.

Hassan, N., Chin, S. T., Yeow, J. A., \& Rom, M. N. A. (2010). Financial Constraints and Opportunities of Micro EntrepriseEntreprenuers: A Theoretical Framework. International Conference on Business and Economics Research (165-168). Kuala Lumpur, Malaysia.

Herhes, G. (2016). Distinguishing micro-businesses from SMEs: A systematic review of growth constraints. Retrieved from:

http://eprints.whiterose.ac.uk/103512/3/WilliamsDistinguishing\%20microbusinesses\%20from\%20SMEs.pdf

Holden, P. (2016). Top reasons why SMEs fail in Malaysia. Retrieved from http://blog.crowdplus.asia/top-reasons-smes-fail-malaysia-crowdplus-asia-can-help/

Ibrahim, M. F., \& Leng, S. K. (2003). Shoppers' perceptions of retail developments: Suburban shopping centres and night markets in Singapore. Journal of Retail \& Leisure Property, 3(2), 176-189. 
Ingram, D. (2019). List and Explain the Characteristics of a Small Scale Business. Retrieved from:https://smallbusiness.chron.com/list-explain-characteristics-small-scalebusiness-10472.html

Isa, C. R., Saleh, Z., \& Sapiei, N. S. (2008). A Survey On Financial and Management Accounting Practices Among Small and Medium Enterprises in Malaysia. Asian Journal of Accounting Perspectives, 1(1), 13-25.

Jamak, A., Salleh, A. B. S., Sivapalan, R. S., \& Abdullah, A. (2011). Entrepreneurial challenges confronting micro-enterprise of Malaysian Malays. World Academy of Science, Engineering and Technology, 5(9), 862-867.

Jamak, A. B. S. A., Ali, R. M. M., \& Ghazali, Z. (2014). A breakout strategy model of Malay (Malaysian indigenous) micro-entrepreneurs. Procedia-Social and Behavioral Sciences, 109, 572-583.

Jindrichovska, I. (2013). Financial Management in SMEs. European Research Studies, XVI(4), 79-96.

Kamau, L., \&Kagiri, A. (2015). Influence of inventory management practices on organizational competitiveness: A case of Safaricom Kenya Ltd. International Academic Journal of Procurement and Supply Chain Management, 1(5), 72-98.

Kamunge, M. S., Njeru, A., \&Tirimba, O. I. (2014). Factors affecting the performance of small and micro enterprises in Limuru town market of Kiambu County, Kenya. International Journal of Scientific and Research Publications, 4(12), 1-20.

Karel, S., Adam, P., \& Radomír, P. (2013). Strategic Planning and Business Performance of Micro, Small and Medium-Sized Enterprises. Journal of Competitiveness, 5(4), 57-72.

Kinyua, A. N. (2014). Factors Affecting the Performance of Small and Medium Enterprises in the Jua Kali Sector In Nakuru Town, Kenya. IOSR Journal of Business and Management, 16(1), 80-93.

Kithae, P. P., Gakure, R. W., \&Munyao, L. M. (2012). The Place of Micro and Small Enterprises in Achievement of Kenya's Vision 2030. Journal of US-China Public Administration, 9(12), 1432-1440.

Kuo, C. T., Chung, M. L., \& Kuo, F. C. (2012). To Explore Taiwanese Night Markets Culture and Tourism Experience and Behaviour. Procedia - Social and Behavioral Sciences, 40, 435-440.

Lee, N., Sameen, H., \& Cowling, M. (2015). Access to finance for innovative SMEs since the financial crisis. Research Policy, 44(2), 370-380.

Luo, Y. (2007). A coopetition perspective of global competition. Journal of World Business, $42,129-144$.

Manaye, M. K., \& Tigro, M. G. (2017). Challenges for Small and Micro Enterprises in Accessing Finance (Case of WolaitaSoddo Town). Global Journal of Management and Business Research Finance, 17(7), 64-73.

Mead, D. C. \&Liedholm, C. (1998). The dynamics of micro and small enterprises in developing countries. World Development, 26(1), 61-74.

Mjongwana, A., \& Kamala, P. N. (2018). Non-financial performance measurement by small and medium sized enterprises operating in the hotel industry in the city of Cape Town. African Journal of Hospitality, Tourism and Leisure, 7(1), 1-26.

Muller, M. (2011). Essential of Inventory Management (2nd ed.). American Management Association. 
Munoz, J. M., Welsh, D. H., Chan, S. H., \& Raven, P. V. (2015). Microenterprises in Malaysia: a preliminary study of the factors for management success. International Entrepreneurship and Management Journal, 11(3), 673-694.

Myeni, S. S. (2018). Cash-Flow Management Strategies in Small and Medium-Sized Occupational Health Enterprises. PhD thesis. Walden University. Retrieved from https://scholarworks. waldenu.edu/cgi/viewcontent.cgi?article=6386\&context=disse rtations

Nunnally, J. C. (1979). Psychometric Theory. McGraw-Hill, New York.

Nyang'au, F. O. (2013). Challenges Facing Micro and Small Enterprises in Inventory Management in Kisii Town, Kenya. IOSR Journal of Business and Management, 13(5), 20-29.

Ogbo, A. \& Hukwu, N. A. C. (2012). The role of entrepreneurship in economic development: The Nigerian perspective. European Journal of Business and Management, 4(8), 95105.

Örnek, A. S. \& Ayas, S. (2015). The Relationship between Intellectual Capital, Innovative Work Behavior and Business Performance Reflection. Procedia - Social and Behavioral Sciences, 195, 1387-1395.

Osotimehin, K. O., Jegede, C. A., Akinlabi, B. H., \& Olajide, O. T. (2012). An evaluation of the challenges and prospects of micro and small scale enterprises development in Nigeria. American International Journal of Contemporary Research, 2(4), 174-185.

Padachi, K. (2010). Accounting Services Among Manufacturing SMEs: A Neglected Subject. Retrieved from http://docplayer.net/5545478-Accounting-services-amongmanufacturing-smes-a-neglected-subject.html

Pallant, J. (2010). SPSS survival manual: $A$ step by step guide to data analysis using SPSS. Open University Press/McGraw-Hill.

Hinton, P. R., Brownlow, C., Mcmurray, I., \& Cozens, B. (2004). SPSS Explained. Routledge.

Petersen, M. A., \& Rajan, G. R. (1994). The Benefits of Lending Relationship: Evidence from Small Business Data. Journal of Finance, 49(1), 3-37.

Piperopoulos, P. (2010). Ethnic minority businesses and immigrant entrepreneurship in Greece. Journal of Small Business and Enterprise Development, 17(1), 139-158.

Sacer, I. M., Malis, S. S., \&Pavic, I. (2016). The Impact of Accounting Estimates on Financial Position and Business Performance - Case of Non-Current Intangible and Tangible Assets. Procedia Economics and Finance, 39, 399-411.

Salazar, A. L., Soto, R. C., \& Mosqueda, R. E. (2012). The Impact of Financial Decisions and Strategy on Small Business Competitiveness. Global Journal of Business Research, 6(2), 332-349.

Salleh, F., Yaakub, N., Mohamad, M., Abd. Ghani M., \& Sulong, W. K. (2012). Demographic Characteristics Differences and Sales Performance among Night Market Traders in Malaysia. International Business Research, 5(4), 25-33.

Selamat, N. H., Abdul-Razak, R. R., Gapor, S. A., \& Sanusi, Z. A. (2011). Survival through entrepreneurship: Determinants of successful micro-enterprises in BalikPulau, Penang Island, Malaysia. British Journal of Arts and Social Sciences, 3(1), 23-37.

Small Business Connect. (2015). Help on the way for township entrepreneurs. Retrieved from http://www.small businessconnect.co.za/news.

SME Annual Report 2016/17. (n.d.). Retrieved from 
http://www.smecorp.gov.my/index.php/en/laporan-tahunan/2150-sme-annualreport-2016-17

SME Corp Malaysia, Micro Enterprises. (2018). Retrieved from https://www.smecorp.gov.my/index.php/en/

Smirat, B. Y. A. (2016). Cash Management Practices and Financial Performance of Small and Medium Enterprises (SMEs) in Jordan. Research Journal of Finance and Accounting, 7(2), 98-107.

Sunday, A., Burani, A., \&Eliabu, B. (2013). Financial Management practices in small and medium Enterprises in selected Districts in western Uganda. Research Journal of Finance and Accounting, 1(2), 29-42.

Tabachnick, B. G., \& Fidell, L. S. (2007). Using Multivariate Statistics (5th ed.). New York: Allyn and Bacon.

Thaker, M. T., Asmy, M., \& Mohamed, M. O. (2015). The challenges of micro enterprises in Malaysia and the prospect for Integrated Cash Waqf Micro Enterprise Investment (ICWME-I) model (In Small and Medium Enterprises (SMES) in some selected muslim countries). IIUM Press, Kuala Lumpur, Malaysia.

Uwonda, G. \& Okello, N. (2015). Cash Flow Management and Sustainability of Small Medium Enterprises (SMEs) in Northern Uganda. International Journal of Social Science and Economics Invention, 1(3), 1-20.

Wanjohi, K. (2009). Appropriate Financing for the MSE sector. The Accountant Journal of the Institute of Certified Public Accountants of Kenya, 17(8), 30-31.

Waters, D. (2003). Inventory Control and Management (2nd ed.). John Wiley \& Sons Ltd.

Waweru, C., \& Ngugi, D. K. (2014). Influence of Financial Management Practices on the Performance of Micro and Small Enterprises in Kenya. European Journal of Business Management, 1(11), 1-20.

Williams, B., \& O'Donovan, G. (2015). The accountants' perspective on sustainable business practices in SMEs. Social Responsibility Journal, 11(3), 641-656.

Wulandari, E., Meuwissen, M. P. M., Karmana M. H., \& Lansink, O. A. G. J. M. (2017). Access to finance from different finance provider types: Farmer knowledge of the requirements. PLOS ONE, 12(9),1-21.

Yıldız, S., Baştürk, F., \& Boz, I. T. (2014). The Effect of Leadership and Innovativeness on Business Performance. Procedia - Social and Behavioral Sciences, 150, 785-793.

Yuliansyah, Y., \& Razimi, A. M. S. (2015). Non-financial performance measures and managerial performance: the mediation role of innovation in an Indonesian stock exchange-listed organization. Problems and Perspectives in Management, 13(4), 135-144.

Zager, K., \& Decman, N. (2016). Guidelines and Recommendations for Improving the Micro Entities Model of Financial Reporting. Procedia Economics and Finance, 39, 451-457.

Zuriekat, M., Salameh, R., \& Alrawashdeh, S. (2011). Participation in Performance Measurement Systems and Level of Satisfaction. International Journal of Business and Social Science, 2(8), 159-169. 